\title{
Appraisal of E-learning structure in Nigerian Polytechnics: A Case study of Federal Polytechnic, Ado Ekiti
}

\author{
Sanmi Adeoti (Mnitp,Rtp), Adebayo, A.A. \\ Department of Urban and Regional Planning Federal Polytechnic, Ado Ekiti. Nigeria \\ Department of Architectural Technology Federal Polytechnic, Ado Ekiti. Nigeria
}

\begin{abstract}
E-learning represents an entirely new learning environment where information and communication systems, whether networked learning or not, serve as specific media to implement the learning process for students. In response to the fast development in Information and Communication Technologies (ICT), e-learning was therefore adopted by many universities and other higher institutions around the globe as a way of improving and supporting their teaching-learning activities and making education accessible for all society members.. Unfortunately, this rapidly changing technological resource along with the ever growing and mobile society has no doubt created many challenges for students, teachers, parents, administrators and policymakers particularly in developing countries. This actually made the paper to assess the e-learning structure in term of physical infrastructure and human development at the Federal Polytechnic, Ado Ekiti through data collected both by structured interview and questionnaires. The analyses of which the states of development are at low realm therefore, call for a robust synergy that will be able to meet and cope with the test of the time.
\end{abstract}

Keywords: Challenges, collaboration, E-learning, Infrastructure, Policymaker

\section{Introduction}

The term "e-learning" originates from electronically-assisted learning, or learning with and through the use of technologies. Other commonly used to explain e-learning terms include online learning, computerassisted learning or ICT in education. E-learning is considered as an innovative approach for delivering electronically, well-designed, learner-centered and interactive learning environments to anyone, anyplace, anytime, most especially by utilizing the internet and digital technologies in line with instructional design principles.[1] E-Learning, therefore, incorporates both content (curriculum) and instruction (pedagogy).

The benefit of e-learning which is numerous, include harnessing network technologies and wireless devices that make teaching and learning to take place within and beyond the traditional classroom environment via electronic learning or e-learning. This allows students in one place to learn from instructors in another place, thus overcoming the physical boundaries and in many instances, time constraints. At the same time, makes students from low income families and those who live far away from the city without the convenience of accessible transport to participate in e-learning, acquire knowledge and obtain training that is aligned with their aspirations and goals. As a matter of fact, many institutions, instructors, and policy makers have taken advantage of the flexibility of online learning to cater to the needs of current and potential students at all levels of education, including those who were unable to attend traditional courses on campus. [2], [3], [4]. In fact, the rapid expansion of ICTs in Nigeria has offered opportunities that promote distance education.

Unfortunately developing countries are still far behind from getting benefit from the e-learning due to very high primary cost of infrastructural development and poor public access to internet and other ICTs. For instance, e-learning in Nigerian tertiary institutions is still a dream because of poor ICT infrastructure and other socio-economic reasons. It is also noted that in Nigeria, while very few of our conventional universities are now carrying out their academic activities through one form of ICT or the other, the urge to embark on e-learning is still a dream to some because their infrastructure of ICT's which is still very weak.

It is against this background that the paper takes a critical look of all the available ICT facilities at the Federal Polytechnic, Ado Ekiti. Along the line, the paper equally examines the development of human resources in the institution. At the same time, it identifies the challenges for proper development of ICT and finally provides appropriate measures that are necessary to promote teaching and learning through ICT.

\section{Review of Literature}

The word E-learning which is known as a modern distance learning is a new form of teaching device by which students, most especially the distant learners are provided access to the learning and instructional materials through any appropriate electronic media such as the mobile phone, television, radio, etc. E-learning is as well considered as distance education that involved all the digital technologies, including: computer, scanner, printer, telephone, internet, digital satellite system (DSS), direct broadcast satellite (DBS), pocket-switching, fiber optic cables, laserdisc, microwaves, and multi-media systems for collection, processing, storage and 
dissemination of information all-over the world.[5] It involves revised curriculum, infrastructure, teacher professional development, textbooks, and exams. [6].This actually makes E-learning as education of the wholesome integration of modern telecommunications equipment known as Information Communication Technology ( ICT) resources, particularly the internet

Generally, e-learning is of two major forms. One is called synchronous and the other is asynchronous. The synchronous simply means "at the same time," and it involves interacting with an instructor via the Web in real time. As a matter of fact, the synchronous form has comprehensive features like the forum chatting and audio-effect that allow for interactivity between the learning content and the learners. Asynchronous on the other hand means "not at the same time," therefore, allows the student to complete the course at their own time and schedule, without live interaction with the instructor.[7] In fact, asynchronous form of e-learning on the other hand is the direct opposite of synchronous form. Whereas, the latter by design has multifarious features, and the former does not. It only presents the learning content for the students to read, internalize and download if need be. Also, whereas synchronous e-learning allows for immediate feedback as much as possible, asynchronous may not necessarily allow for immediate feedback

Developing countries are faced with many e learning challenges. Thai universities revealed that instructors and students faced great challenges with e learning with reports that all instructors interviewed had little or no experience with online teaching methodology and consequently lacked confidence in implementation of e learning. [8]. He further pointed out that the students have poor availability of access points, slow network communications, and lack of software application as their challenges to participating in e-learning. At the same time, these findings equally noted that Thai instructors had failed to see the value of e-learning and were disinterested in implementing e-learning, while students complained about the poor ICT infrastructure [9]

The major problems facing the proper implementation of e-learning in Nigerian tertiary institutions are the high cost of computer and laptop when considering the income level of an average worker in Nigeria. In fact, very few people have access to computer and in most cases, the very few who have access to the computer do not know how to use it and maximize it usage.[10] At the same time, explained further that the cost of accessing internet is still very high in Nigeria where most students that make use of Cyber Café paid between \#100.00 and \#150.00 per hour despite their poor services and slow rate of their server. Other major challenges pointed out are reliable power infrastructure, adequate computer hardware and software together with bandwidth management for audio and graphic data transfer and security[11].

Despite all the hindrances/threat faced by e-learning in Nigeria the National Universities Commission in the last three decade has worked to lay the foundation for e-learning through investment in ICT infrastructure, management information systems, e-mail access and library information services. Institutions such as RECTAS, Federal School of Surveying, Oyo, University of Ibadan and Obafemi Awolowo University (OAU) Ile-Ife University of Benin, University of Abuja, University of Lagos, among others has the facilities for elearning.[12]. The number seems very low (compared to other parts of the world and the usefulness of the elearning in the economy development) because of location of most institutions, bandwidth issue and mostly the challenge of electricity. For instance, Nigeria which is the most populous country on the African continent ranks 62 among nations in terms of institutional e-readiness, the ability of a nation's institutions to use ICT to achieve their mission and vision below South Africa and Egypt which rank 39 and 57 respectively[13]

For many years, e learning globally has received various form of technical assistance. For instance, Hewlett Packard (HP) has contributed in five years a total of nearly $\$ 60$ million to more than 1,000 schools in 41 countries worldwide and had in the past 20 years, contributed more than $\$ 1$ billion in cash and equipment to schools, universities, community organizations and other nonprofit organizations around the world. [13] $\mathrm{He}$ further pointed out that in 2008, the University of Jos received a significant boost to provide funds for hardware, software and training when it emerged the only university in Nigeria to share in HP's \$3.6 million corporate social responsibility project aimed at empowering about 36 universities in Europe, Middle East and Africa with cash and equipment. Other beneficiaries in Africa included the Makerere University Uganda and University of the Free State, South Africa. At the same time, Jos-Carnegie funds were also used to purchase 19 personal computers, three printers, and one diesel generating plant for backup power supply including Scientific Workplace Version 5.0 software.

\section{Study Area and Method}

The study area which is the Federal Polytechnic Ado Ekiti was initially established at Jos in 1977 with student enrolment of 350 (Full time National Diploma) in only seven academic departments. However, the polytechnic was completely moved to Ado Ekiti in 1985 with student population strength of 2,517 in 1989 . Presently, the student population has increased to 10,000 (Full time and part time) at National and Higher National Diploma which spread across five schools and 22 departments.

The polytechnic since inception has equally been enjoying an appreciably consistent measure of staff growth. In 1978, the polytechnic had about 95 senior staff which rose to 261 in 1989, of which the junior staff 
increased the figure to 740. Right now, both the academic and non academic staff of the polytechnic is over 1000 .

The study employed a survey research design that aim at determining the level of ICT facilities, human development and constraints. The compilation of data which was majorly through primary survey involved field observation, questionnaires and structure interview as design instrument. A total number of 360 questionnaires were randomly distributed among students and staff across all the departments including the polytechnic library. The distribution and retrieval of data was a week exercise and it was carried out by trained students. The analysis of the collected data was purely descriptive which involves the use of quantitative tables and graphs for the presentation of the data,

\section{Results of Findings}

The data collected actually involved both the human and physical infrastructure and the major constraints. They were all analyzed under the headings below

\subsection{The Human Resources}

The human resources are all about the staff and student development. In fact, the staff development variables include the level of ICT knowledge; ICT training attended; Type of ICT training and their teaching format. At the same time, the student development variables are student background, form of their computer devices, and format of their computer device usage

It is interesting to note from the Table 1 below that majority of the staff are computer literate but not fully ICT compliance while less than 10 percent of the staff are completely illiterate in computer and ICT.

Table 1: Staff ICT Knowledge

\begin{tabular}{|l|l|l|}
\hline ICT knowledge & No of respondents & Percentage \\
\hline ICT and computer literate & 15 & 25 \\
\hline Computer literate without ICT & 40 & 67 \\
\hline ICT and computer illiterate & 5 & 8 \\
\hline
\end{tabular}

Source: Fieldwork 2014

As revealed in Table 2, majority of the staff have not participated in any ICT training programme followed by those who have participated once while those who have participated more than once have the least percentage.

Table 2: ICT Training Attendance

\begin{tabular}{|l|l|l|}
\hline No of ICT training & No of respondents & Percentage \\
\hline Once & 12 & 20 \\
\hline More than once & 3 & 5 \\
\hline None of the above & 45 & 75 \\
\hline
\end{tabular}

Source: Fieldwork 2014

In the same vein, it is noted in Table 3 that majority of the staff that participated in ICT training was through in house programme while very few of them did their training outside.

Table 3: ICT Training Mode

\begin{tabular}{|l|l|l|}
\hline Training location & No of respondents & Percentage \\
\hline In-house training & 13 & 21.67 \\
\hline Out side training & 2 & 3.33 \\
\hline None of the above & 45 & 75 \\
\hline
\end{tabular}

Source: Fieldwork 2014

The traditional method of class room interaction between students and tutors still remains the only format of impacting knowledge to the student as indicated in Table below. However, slide projection is used occasionally. In fact, close circuit television system remains dormant.

Table 4: Teaching Format

\begin{tabular}{|l|l|l|}
\hline Teaching method & No of respondents & Percentage \\
\hline Chalk board teaching & 56 & 93.33 \\
\hline Slide projection & 4 & 6.67 \\
\hline Close circuit TV & 0 & 0 \\
\hline
\end{tabular}

Source: Fieldwork 2014

The variables considered for the student e-learning development include the student background, their available computer devices and the usage of the devices.

Available data indicated that majority of the student are computer literate with computer device while those who are computer illiterate and without computer constituted the minority. See the Table below. 
Appraisal of E-learning structure in Nigerian Polytechnics: A Case study of Federal Polytechnic....

Table 5: Student Background

\begin{tabular}{|l|l|l|}
\hline Student background & No of respondents & Percentage \\
\hline Computer literate/computer device & 234 & 78 \\
\hline Computer literate only & 15 & 5 \\
\hline Computer illiterate & 51 & 17 \\
\hline
\end{tabular}

Source: Fieldwork 2014

As a mater fact, majority of these students are only in possession of mobile phone. This is followed by those with laptop and mobile phone while those with none formed the least category. See the Table below.

Table 6: Computer Devices Possession

Source: Fieldwork 2014

\begin{tabular}{|l|l|l|}
\hline Computer devices & No of respondents & Percentage \\
\hline Browsing phone only & 138 & 46 \\
\hline Browsing phone/laptop & 90 & 30 \\
\hline None of the above & 72 & 24 \\
\hline
\end{tabular}

Majority of the students use the computer devices as tool to perform a task. However some use them as source to acquire knowledge while none of the students see these devices as unserviceable.

Table 7: Computer Devices Usage

\begin{tabular}{|l|l|l|}
\hline Computer devices usage & No of respondents & Percentage \\
\hline Task performing tools & 93 & 31 \\
\hline Source of knowledge & 135 & 45 \\
\hline None of the above & 72 & 24 \\
\hline
\end{tabular}

Source: Fieldwork 2014

\subsection{Physical infrastructure}

Data collected on ICT physical infrastructure are of two forms. They are buildings and the necessary tools. The polytechnic has five ICT buildings, namely the digital library, the ICT training center, ICT secretariat and two ICT resource centers. The necessary tools include computer system with wireless connectivity, computer system with cable connectivity, local server, internet services projector with screen, multimedia, printer and scanner.

The digital library and the training center are provided with the highest number of facilities. The secretariat is next in the provision of some necessary facilities while the two

Resource centers are yet to be provided with necessary tools as shown in the Table below.

Table 8: ICT Facilities

\begin{tabular}{|l|l|l|l|l|}
\hline $\begin{array}{c}\text { Buildings } \\
\text { Tools }\end{array}$ & $\begin{array}{l}\text { Digital } \\
\text { library }\end{array}$ & $\begin{array}{l}\text { Training } \\
\text { center }\end{array}$ & $\begin{array}{l}\text { Secretariat } \\
\text { building }\end{array}$ & $\begin{array}{l}\text { Resource } \\
\text { center }\end{array}$ \\
\hline Wireless computer & - & $\mathrm{x}$ & - & - \\
\hline Cable computer & $\mathrm{x}$ & - & $\mathrm{x}$ & - \\
\hline Local server & - & $\mathrm{x}$ & $\mathrm{x}$ & - \\
\hline Internet service & $\mathrm{x}$ & $\mathrm{x}$ & - & - \\
\hline Projector/screen & $\mathrm{x}$ & $\mathrm{x}$ & $\mathrm{x}$ & - \\
\hline Multimedia & $\mathrm{x}$ & - & - & - \\
\hline Printer & $\mathrm{x}$ & $\mathrm{x}$ & - & - \\
\hline Scanner & $\mathrm{x}$ & $\mathrm{x}$ & - & - \\
\hline
\end{tabular}

Source: Fieldwork 2014

\subsection{Major Constraints}

The noticeable major constraints for e-learning in the polytechnic by both staff and the students are poor and high cost of internet services as well as erratic power supply. However, the management considered lack of funds and technical assistance both local and international as the major challenge to develop e-learning.

\section{Discussion of Findings}

Basically there is no gainsaying of the fact that both human and physical infrastructure developments are very paramount for e-learning. Unfortunately they have not fully developed at the Federal Polytechnic. For instance, many staff is not ICT compliance even though they claimed to be computer literate as result of their Microsoft knowledge in computer. This is attributed to the low level of ICT staff training and development. The physical infrastructure is also not only inadequate in term of buildings; they are as well not properly equipped with computer facilities. Available records confirmed that ICT materials such as computers, printers, scanners, e-books, textbooks, workbooks and books on ICT are not available and not in use in Nigerian schools for computer education.[14], [15] 
The poor infrastructure development has no doubt led to weak e-learning process. The poor internet services and erratic power supply actually make almost all the academic staff to find it difficult to prepare and deliver their lectures through e-learning. At the same time, most students are unable to receive and enjoy the benefits of e-learning. In fact, the few benefits enjoy by some students are costly because they do not have access to polytechnic internet services Again, the findings no doubt agree with fact which revealed that few students that are privileged to have a PC/Laptop are not connected to the internet as this does attract extra cost which they cannot always afford.[10]

\section{Conclusion}

E-learning is a modern pedagogy of which the applications and process include computer-based learning, web-based learning, virtual classroom and digital collaboration where contents are delivered via the internet, intranet/extranet, audio and or video tapes, satellite TV and CD-ROM. Unfortunately, e-Learning programs in developing countries and Nigeria in particular are still often small, experiential pilot projects with little documented history of their successes and impacts.

The building of the physical infrastructure as well as the knowledge infrastructure base such as teacher training, teaching materials and Internet facilities are necessary before the full benefits of the e-learning educational investments can be realized. The development of these infrastructures is noted to be at low realm in almost all higher institutions in the county. The findings of this paper reveal that the polytechnic is experiencing critical challenges such as poor infrastructure, a lack of teachers and learning material, and poorly prepared students on e-learning.

Consequent upon these findings of this study, the following recommendations were made for prospective and effective e-learning:

- Conferences, workshops and symposium should be organized by the polytechnic to train their staff and enlighten them on the need for e-learning

- Provision of fully computerized laboratory and classroom in each school of the Polytechnic for e-learning.

- Provision of improved bandwidth/fast internet connectivity and availability of reliable electricity

- The institution should put in place an effective ICT board that will oversee the implementation of elearning, and facilitate increased access to capital

- The institution administration should discard the idea of providing for e-learning alone rather, they should go into public and private partnership for funding

\section{References}

[1]. Hedge, N. and Hayward, L. (2004). Redefining roles. University e-learning contributing to Life-long learning in a networked world. ELearning, 1:128 - 145 http://www.nationmaster.com/country/ni/Internet

[2]. Cheung, W. \& Huang, W Proposing a framework to assess Internet usage in university education: An empirical investigation from a student's perspective. British Journal of Educational Technology, 36(2) 2005, 237-254

[3]. Dawson,S. Online forum discussion interactions as an indicator of student community. .Australasian Journal of Educational Technology, 22 (4), (2006) 495-510.http://www.ascilite.org.au/ajet/ajet22/dawson.html5.

[4]. Johnson, E. M., Cowie, B., De Lange, W., Falloon, G., Hight, C. \& Khoo, E. (2011). Adoption of innovative e-learning support for teaching: A multiple case study at the University of Waikato. Australasian Journal of Educational Technology, 27(3),(2011) 499513.http://www.ascilite.org.au/ajet/ajet27/johnson.html

[5]. Shavinina, L.V. (2001). A new generation of educational multimedia: High intellectual and creative educational multimedia technologies. New York: Mary Ann Liberty Publishers

[6]. Uden, L., Damiani, E., Wangsa, I. (2007). The future of E-learning: E-learning ecosystem. Inaugural IEEE International Conference on Digital Ecosystems and Technologies, 21 February 2007: 113-117.

[7]. Aboderin, O. S. and Kumuyi,G. J.(2013).The Problems and Prospects of E-Learning in Curriculum Implementation in Secondary Schools in Ondo State, Nigeria International Journal of Educational Research and Technology IJERT:4 [1] : 90 - 96 Website:

www.soeagra.com/ijert/ijert.htm

[8]. Emmanuel O A, Ifeoma R. E, Ekima T S, Jackson M. N (2013) E-Learning and Distance Education in Nigeria, International Journal of Science and Technology 2. (2) 203-210

[9]. Saekow, A. \& Samson, D. (2011). E-learning readiness of Thailand's universities comparing to the USA's cases. International Journal of eEducation, e-Business, e-Management and e-Learning, 1(2), 126-131. http://www.ijeeee.org/Papers/020-Z0001.pdf

[10]. Salawudeen, O.S. (2010) E-learning Technology. The Nigerian Experience, Roger Printing and Publishing limited, Abuja

[11]. Ogunsote,O.O, Omofaye, J.O, Ogunsote,B.P(2006) The challenges of e-learning in architectural education: A case study of the Federal University of Technology, Yola, A Paper presented at Annual Conference of the Association of Architectural Educators in Nigeria, Oct, $21^{\text {st }}$ $27^{\text {th }}$.

[12]. Ajadi, T.O, Salawu, I, O and Adeoye, O A (2008) E-Learning and Distance Education in Nigeria The Turkish Online Journal of Educational Technology - TOJET 7 61-70

[13]. Livepool, L .S. and Marut, M. J (2009) Towards a model for e-learning in Nigerian HEIs: Lessons from the University of Jos ICT Maths Initiative

[14]. Effiong, J.E. (2005). Business education in the era of information and communication technology: Issues, problems and prospects. Business Education Journal, 5(1) $3-7$.

[15]. Jegede, P.O. \& Owolabi, A.J. (2003). Computer education in Nigerian secondary schools: Gaps between policy and practice. Meridian: A Middle School Technology Journal, 6(2) 1 - 11. Retrieved from http://www.ncsu.edu/meridian/sum2003/nigeria/nigeria.pdf.

[16]. Uden, L., Damiani, E., Wangsa, I. (2007). The future of E-learning: E-learning ecosystem. Inaugural IEEE International Conference on Digital Ecosystems and Technologies, 21 February 2007: 113-117. 